\title{
"The discomfort is still there, but I do not care much about it!" The Therapeutic Role of the Transference Relationship between the Patient Suffering from Complex Oral Sensitivity Disorder and the Oral Health-care Provider
}

Giulio Fortuna ${ }^{1,2,3 *}$

Received: 18 May 2016; Returned for revision: 22 May 2016; Received in revised form: 23 June 2016; Accepted: 24 June 2016; Published online: 26 June 2016

(C) The author(s) 2016. Published with open access at www.uscip.us

"Love, work, and knowledge are the wellspring of our life. They should also govern it."

(W. Reich, 1933)

The analysis of the co-occurrence of different intra-oral symptoms other than burning and several unexplained extra-oral symptoms reported by patients suffering from burning mouth syndrome (BMS) and psychiatric comorbidities, such as anxiety and depression, (Schiavone et al., 2012; de Souza et al., 2012) hypochondria and cancerophobia (de Souza et al., 2012), has led to the notion that BMS is a much more complex disease. BMS may belong to the category of an undifferentiated somatoform disorder (Mignogna et al., 2011). Additionally, a recent study has demonstrated that specific BMS symptoms are associated with excessive psychiatric symptoms, such as anxiety with taste changes and oral malodor, and depression with metallic taste and a sensation of film on the gums (Davies et al., 2016).

It has been postulated that all the current alternative terminologies of BMS, such as glossodynia, glossopyrosis and oral dysesthesia, and classification as primary and secondary (Scala et al., 2003) and/or type I, II, and III (Muzyka and De Rossi, 1999; Lamey and Lewis, 1989) are inaccurate and not sufficiently comprehensive to explain the complexity of symptoms associated with this disease (Fortuna et al., 2013; Fortuna and Pollio, 2012a and b).

\footnotetext{
*Corresponding e-mail: giulio.fortuna@gmail.com

1 Department of Diagnostic Sciences, Louisiana State University School of Dentistry, 1100 Florida Ave, New Orleans, LA 70124, USA.

2 Federico Navarro Institute - School of Orgonomy "Piero Borrelli", Corso Umberto I, 35, 80138, Naples, Italy. 3 D.eb.RA. Mexico Foundation, Otomí \#211, casi esq. P. Elías Calles Colonia Azteca, Guadalupe N.L., 67150, Monterrey, Nuevo Leon, Mexico.
} 
Therefore, the new terminology "Complex Oral Sensitivity Disorder" (COSD) was proposed, although not validated or field tested yet (Fortuna et al., 2013). The related diagnostic criteria remain, to some extent, quite broad, but more accurate than those proposed by both the International Headache Society (IHS) (Headache Classifications Subcommittee of the International Headache Society, 2004) and the International Association of the Study of Pain (IASP) (Merksey and Bogduk, 1994).

The absence of more specific diagnostic criteria and definition seems to reside in its etiopathogenesis that still remains controversial, because it may involve multiple aspects (Balasubramaniam et al., 2009): local, such as salivary gland dysfunction (Granot and Nagler, 2005), altered mineral salivary composition (Pekiner et al., 2009; Cho et al., 2010), altered mucosal blood flow (Heckmann et al., 2001), and systemic factors, such as hormonal imbalance (Gao et al., 2009) hematinic-vitamin deficiency (Lin et al., 2012), serum cytokines level (Pekiner et al., 2008), taste damage (Bartoshuk et al., 2005), chorda tympani dysfunction (Eliav et al., 2007), and steroid dysregulation (Woda et al., 2009).

Similarly, neuropathic mechanisms due to central (Albuquerque et al., 2006; Jaaskelainen et al., 2001; Hagelberg et al., 2003) and peripheral (Ito et al., 2002; Granot and Nagler, 2005; Lauria, et al., 2005; Just et al., 2010) nervous system impairment as well as psychiatric/psychosocial disturbances (Amenabar et al., 2008; Malik et al., 2011; Mignogna et al., 2011; de Souza et al., 2012; Schiavone et al., 2012; Adamo et al., 2013; Lopez-Jornet et al., 2015) have been implicated.

Therefore, it is not surprising that diagnosis and management still appear an enormous challenge and enigma (Klasser et al., 2008; Klasser et al., 2011b). Indeed, there is no universally accepted and definitive therapy for COSD. Rather, there are multiple therapeutic approaches (Klasser et al., 2011a), mainly based on patients' symptoms (Klasser et al., 2011b). Those include pharmacological (topical and systemic) such as anesthetics (Sardella et al., 1999), benzodiazepine (Grushka et al., 1998; Gremeau-Richard et al., 2004; Amos et al., 2011; Ko et al., 2012), antidepressants (Maina et al., 2002; Yamazaki et al., 2009), and atypical antipsychotic agents (Maina et al., 2002; RodriguezCerdeira and Sanchez-Blanco, 2012); non-pharmacological, such alpha lipoic acid (Femiano et al., 2000; Femiano and Scully, 2004; Palacios-Sánchez et al., 2015) acupuncture (Jurisic Kvesic et al., 2015; Sardella et al., 2013), herbal-homeopathic remedies (Sardella et al., 2008; Spanemberg et al., 2012; López-Jornet et al 2011b; López-Jornet et al 2013; Cano-Carrillo et al., 2014; Valenzuela at al., 2015), tongue protector (López-Jornet P, et al 2011a), capsaicin (Petruzzi et al., 2004; Marino et al., 2010; Silvestre et al., 2012), vitamin and mineral supplement (Cho et al., 2010; Sun et al., 2013), and psychological, such as cognitive-behavioral therapy (Bergdahl et al., 1995; Humphris et al., 1996). All of them can be used alone or in combination.

Many of the above-mentioned interventions are based on randomized double-blind controlled trials, in which the study group has demonstrated statistically significant beneficial effects as compared to the control group, confirming the initial hypothesis "that specific medication/intervention" has helped the patient to improve his/her oral symptoms and possibly his/her quality of life.

However, interestingly enough, it has been recently shown that a spontaneous resolution of the symptoms may occur in a portion of the control population as a result of treatment with a placebo. 
The mean placebo response as a fraction of drug response over ten studies was $72 \%$, suggesting a robust placebo response (Kuten-Shorrer et al., 2014).

Those data have been recently confirmed by another study, showing that a simple informative intervention where clinicians reassure the BMS patient about his/her condition resulted in a significant reduction of symptoms and better quality of life (Brailo et al., 2016).

These findings seem to support the concept that the oral health-care provider plays a pivotal role in the overall management of COSD patients.

Over the past 10 years, I have had the chance of seeing several hundreds of COSD patients and, at the beginning of my career as a clinician and scientist, I really thought that a "simple medication" and "15-minute consultation and delivery of diagnosis" were adequate to lead those patients to a complete clinical remission. I was very wrong, and now I approach these individuals in a different way.

There is no doubt that medications are definitely helpful in controlling oral symptoms, but are those medications alone capable of giving long-term satisfactory results to the patient?

At their initial visit, many COSD patients start their story by reporting that their oral symptoms began immediately after a dental appointment, such as a hygiene session, or a restorative or endodontic treatment. They blame their dentist, thinking for instance that he/she did not use sterile instruments and passed them some sort of infections.

Then, they report seeking help from one practitioner only to end up seeing multiple providers, but they usually encounter the following all-too-familiar dialogue: "You are healthy! There is nothing wrong inside your mouth!" These patients then present to us with a heavy and thick folder/binder full of clinical data, laboratory investigations, and radiological images.

How is it possible that they have such debilitating oral symptoms if there is nothing visibly wrong inside their mouths? This usually generates a profound feeling of frustration. Patients start to feel scared, exhausted, tired, defeatist, fed up, bored, hostile, and closed to any dialogue, resulting in alterations to their social life, and isolation from family, friends, and colleagues. In turn, this latter group begins to think that it has become too difficult and burdensome to keep up with whomever in the family is tormented by these symptoms, thus abandoning the patient both physically and/or emotionally.

I have heard many times: "I am sorry, doctor, but I do not feel comfortable in socializing, such as having a dinner with my friends or husband/wife or sons/daughters anymore, because of this (pointing at their mouth). I just want to stay at home and be alone". I have very often seen COSD patients crying in desperate need of help, and some have even admitted to contemplating suicide.

At this point, our primary responsibility is to validate their signs and symptoms, telling them - and whomever is with him/her in the consultation room - that those symptoms represent a real specific disease, that fortunately it is not a life-threatening disease per se, but, rather, one that can be extremely debilitating. 
This seems to be a crucial moment for the patients: after many months - or sometimes even years, somebody told them and their relatives that they are not "crazy", and that they have not been imagining their symptoms. Thus, they start feeling slightly relieved and often start crying, because they perceive that they might have found the "right" doctor, as their last hope.

This may represent the beginning of an early empathic relationship (therapeutic immediacy) (Hoglend, 2014) between the patient and the oral health-care provider, which will result in a great positive benefit in terms of patient management.

However, at the initial consultation and diagnosis phase, COSD patients still expect "something" to treat their symptoms. This should be based on the current knowledge of COSD treatment as described in the literature. However, in the long-term a medication-based therapeutic approach alone might not be sufficient for many COSD patients.

Interestingly, many patients tend to report their oral symptoms immediately and then seem to forget the reason why they have come and start talking about many other apparently unrelated issues: their past, their family/relatives, their friends/foes, their hobbies, their job, their vacation, their pets, and so on. Indeed, during follow-up appointments, I prefer beginning the conversation with my patients by asking them about several things they mentioned at their previous visit. It can be related to their oral symptoms or not; it does not matter, because patients know that they have found somebody who cares for them, and not by just simply prescribing medications, vitamins, or nightguards.

This means that when COSD patients present, they are not simply describing their oral symptom(s), but rather their entire lives.

I have in fact learned from my patients that a predominant role in their management is related to the "transference relationship", those aspects of the patient-provider relationship involving transference defined as "the patient's patterns of feelings, thoughts, perceptions, and behavior that emerge within the therapeutic relationship" (Hoglend, 2014).

However, in this context, I used this term to indicate an emotional entanglement between the oral health-care provider and the patient, characterized by verbal and non-verbal interactions, conveying physical and/or emotional closeness, warmness, and affection, with the ultimate aim to improve the patient's oral discomfort and, thus, their quality of life.

In fact, at some moment, during the period of management, when the transference relationship has become well established, regardless of the therapeutic approach being administered, you will be hearing from the patient: "Well doctor, I feel much better; actually the discomfort is still there, but I do not care much about it!"; "I have been returning to my normal life: I started going out with my friends and family, enjoying a meal with them. I have also begun a new hobby or... I have come back to my previous hobby"; "Thank you, doctor! You saved my life! Now, I am happy and my family is happy as well".

How is it possible that they are happy and that "we saved their lives" if their discomfort - although decreased in intensity - is still present in the oral cavity? 
Due to the transference relationship, which has become stronger and stronger through multiple (and more frequent, at least initially), appointments, COSD patients sense reassurance, as previously demonstrated (Brailo et al. 2016), are listened to, and feel supported not only scientifically but emotionally, which provides them with hope. They very likely have learnt how to gradually move the dimension of their problem: since their quality of life has remarkably improved, this clearly outweighs their oral symptoms, and there is no doubt that the empathic role of the oral health-care provider is a significant part of this healing process, which requires time, patience, and love.

After many years of experience with COSD patients and having listened to a vast variety of different stories, I now have this ultimate goal in my mind when I treat them, since the complete resolution of oral symptoms cannot always be obtained in every COSD patient.

COSD patients will also become aware that you are the person/oral health-care provider they can trust and rely upon. They will understand what condition they are experiencing, and gradually accept it, resulting in an active participation of the patient in the overall therapeutic plan and better compliance.

When oral discomfort subsides - although not totally disappeared - and the patient has returned to his/her normal life with serenity and satisfaction, this might be the right time to discuss possible psychological interventions, because they now trust you and are prepared to comply with your recommendations. They have now become convinced that the dental visit was just the triggering event and not the real cause of their symptomatology and that part or all of their oral discomfort may derive from physical and/or emotional event(s) dating back many years.

Therefore, oral health-care providers who want to embark upon this challenging field require not only a high level of knowledge but also a caring attitude with excellent communication skills as every patient is unique in their presentation, and requires an individualized tailored treatment plan based on the COSD patient's disposition. Patient confidence is paramount; hence, privacy is necessary. In some cases, family members or friends should be encouraged to leave the consultation room.

In conclusion, based on my clinical experience, treatment for COSD patients cannot rely exclusively upon a pharmacologic/psychotherapeutic approach, without the active intervention of an oral health-care provider. I have learnt how a strong transference relationship between the oral healthcare provider and the COSD patient will result in remarkable therapeutic effects contributing to the patient's understanding of his/her disease, diseases acceptance, and compliance to different therapeutic options. I am convinced that this aspect should be incorporated into COSD patient-oral health-care provider communication/relation, as a part of the overall management aimed at supporting and integrating patient's pharmacological treatment plan.

This is also what I teach in my undergraduate and postgraduate oral medicine courses: when it comes to treating COSD patients, the goal is to obtain the most efficacious therapeutic effect.

Of course, I would like to hear from my colleagues, and I invite them to share their personal experience with COSD patients in the Journal. 
Giulio Fortuna / American Journal of Oral Medicine

(2016) Vol. 2 No. 1 pp. 11-20

\section{Acknowledgements}

I would like to thank Prof. Gary Klasser and reviewers for their invaluable feedback

\section{Conflict of Interest}

None

\section{Funding}

None

\section{References}

Adamo, D., Schiavone, V., Aria, M., Leuci, S., Ruoppo, E., Dell'Aversana, G. \& Mignogna, M. D. (2013). Sleep disturbance in patients with burning mouth syndrome: a case-control study. J Orofac Pain, 27 (4), 304313. http://dx.doi.org/10.11607/jop.1109

Albuquerque, R. J., de Leeuw, R., Carlson, C. R., Okeson, J. P., Miller, C. S. \& Andersen, A. H. (2006). Cerebral activation during thermal stimulation of patients who have burning mouth disorder: an fMRI study. Pain, 122 (3), 223-234. http://dx.doi.org/S0304-3959(06)00048-0 [pii]10.1016/j.pain.2006.01.020

Amenabar, J. M., Pawlowski, J., Hilgert, J. B., Hugo, F. N., Bandeira, D., Lhuller, F. \& Lopes de Souza, M. A. (2008). Anxiety and salivary cortisol levels in patients with burning mouth syndrome: case-control study. Oral Surg Oral Med Oral Pathol Oral Radiol Endod, 105 (4), 460-465. http://dx.doi.org/10.1016/j.tripleo.2007.10.002 S1079-2104(07)00822-0 [pii]

Amos, K., Yeoh, S. C. \& Farah, C. S. (2011). Combined topical and systemic clonazepam therapy for the management of burning mouth syndrome: a retrospective pilot study. J Orofac Pain, 25 (2), 125-130.

Balasubramaniam, R., Klasser, G. D. \& Delcanho, R. (2009). Separating oral burning from burning mouth syndrome: unravelling a diagnostic enigma. Aust Dent J, 54 (4), 293-299. http://dx.doi.org/10.1111/i.1834-7819.2009.01153.x ADJ1153 [pii]

Bartoshuk, L. M., Snyder, D. J., Grushka, M., Berger, A. M., Duffy, V. B. \& Kveton, J. F. (2005). Taste damage: previously unsuspected consequences. Chem Senses, 30 Suppl 1 i218-219. http://dx.doi.org/30/suppl 1/i218 [pii]10.1093/chemse/bjh192

Bergdahl, J., Anneroth, G. \& Perris, H. (1995). Cognitive therapy in the treatment of patients with resistant burning mouth syndrome: a controlled study. J Oral Pathol Med, 24 (5), 213-215.

Brailo, V., Firic, M., Vucicevic Boras, V., Andabak Rogulj, A., Krstevski, I. \& Alajbeg, I. (2016). Impact of reassurance on pain perception in patients with primary burning mouth syndrome. Oral Dis, http://dx.doi.org/10.1111/odi.12493

Cano-Carrillo, P., Pons-Fuster, A. \& Lopez-Jornet, P. (2014). Efficacy of lycopene-enriched virgin olive oil for treating burning mouth syndrome: a double-blind randomised. J Oral Rehabil, 41 (4), 296-305. http://dx.doi.org/10.1111/joor.12147

Cho, G. S., Han, M. W., Lee, B., Roh, J. L., Choi, S. H., Cho, K. J., .. Kim, S. Y. (2010). Zinc deficiency may be a cause of burning mouth syndrome as zinc replacement therapy has therapeutic effects. J Oral Pathol Med, 39 (9), 722-727. http://dx.doi.org/10.1111/i.1600-0714.2010.00914.x JOP914 [pii]

Davies, S. J., Underhill, H. C., Abdel-Karim, A., Christmas, D. M., Bolea-Alamanac, B. M., Potokar, J., ... Prime, S. S. (2016). Individual oral symptoms in burning mouth syndrome may be associated differentially with 
Giulio Fortuna / American Journal of Oral Medicine

(2016) Vol. 2 No. 1 pp. 11-20

depression and anxiety. Acta Odontol Scand, 74 (2), 155-160. http://dx.doi.org/10.3109/00016357.2015.1100324

de Souza, F. T., Teixeira, A. L., Amaral, T. M., dos Santos, T. P., Abreu, M. H., Silva, T. A. \& Kummer, A. (2012).

Psychiatric disorders in burning mouth syndrome. J Psychosom Res, 72 (2), 142-146. http://dx.doi.org/10.1016/i.jpsychores.2011.11.008S0022-3999(11)00281-9 [pii]

Eliav, E., Kamran, B., Schaham, R., Czerninski, R., Gracely, R. H. \& Benoliel, R. (2007). Evidence of chorda tympani dysfunction in patients with burning mouth syndrome. J Am Dent Assoc, 138 (5), 628-633. http://dx.doi.org/S0002-8177(14)62364-3 [pii]

Femiano, F., Gombos, F. \& Scully, C. (2004). Burning mouth syndrome: the efficacy of lipoic acid on subgroups. J Eur Acad Dermatol Venereol, 18 (6), 676-678. http://dx.doi.org/IDV1049 [pii]10.1111/j.1468-3083.2004.01049.x

Femiano, F., Gombos, F., Scully, C., Busciolano, M. \& De Luca, P. (2000). Burning mouth syndrome (BMS): controlled open trial of the efficacy of alpha-lipoic acid (thioctic acid) on symptomatology. Oral Dis, 6 (5), 274-277.

Fortuna, G., Di Lorenzo, M. \& Pollio, A. (2013). Complex oral sensitivity disorder: a reappraisal of current classification of burning mouth syndrome. Oral Dis, 19 (7), 730-732. http://dx.doi.org/10.1111/odi.12066

Fortuna, G. \& Pollio, A. (2012a). Comment: probable clindamycin-induced ageusia, xerostomia, and burning mouth syndrome. Ann Pharmacother, 46 (11), 1577-1578; author reply 1578. http://dx.doi.org/10.1345/aph.1R234a aph.1R234a [pii]

Fortuna, G. \& Pollio, A. (2012b). Drug-induced burning mouth syndrome: a new clinico-pathological entity? J Headache Pain, 13 (8), 685-686. http://dx.doi.org/10.1007/s10194-012-0486-x

Gao, J., Chen, L., Zhou, J. \& Peng, J. (2009). A case-control study on etiological factors involved in patients with burning mouth syndrome. J Oral Pathol Med, 38 (1), 24-28. http://dx.doi.org/10.1111/j.1600-0714.2008.00708.x JOP708 [pii]

Granot, M. \& Nagler, R. M. (2005). Association between regional idiopathic neuropathy and salivary involvement as the possible mechanism for oral sensory complaints. J Pain, 6 (9), 581-587. http://dx.doi.org/S1526-5900(05)00593-6 [pii]10.1016/j.jpain.2005.03.010

Gremeau-Richard, C., Woda, A., Navez, M. L., Attal, N., Bouhassira, D., Gagnieu, M. C., ... Tubert, S. (2004). Topical clonazepam in stomatodynia: a randomised placebo-controlled study. Pain, 108 (1-2), 51-57. http://dx.doi.org/10.1016/i.pain.2003.12.002 S0304395903004834 [pii]

Grushka, M., Epstein, J. \& Mott, A. (1998). An open-label, dose escalation pilot study of the effect of clonazepam in burning mouth syndrome. Oral Surg Oral Med Oral Pathol Oral Radiol Endod, 86 (5), 557-561. http://dx.doi.org/S1079-2104(98)90345-6 [pii]

Hagelberg, N., Forssell, H., Rinne, J. O., Scheinin, H., Taiminen, T., Aalto, S., .. Jaaskelainen, S. (2003). Striatal dopamine D1 and D2 receptors in burning mouth syndrome. Pain, 101 (1-2), 149-154. http://dx.doi.org/S0304395902003238 [pii]

Heckmann, S. M., Heckmann, J. G., HiIz, M. J., Popp, M., Marthol, H., Neundorfer, B. \& Hummel, T. (2001). Oral mucosal blood flow in patients with burning mouth syndrome. Pain, 90 (3), 281-286. http://dx.doi.org/S0304395900004103 [pii]

Headache Classifications Subcommittee of the International Headache Society (2004). The international classification of headache disorders: 2nd edition. Cephalalgia 24(Suppl 1): 9-160.

Hoglend, P. (2014). Exploration of the patient-therapist relationship in psychotherapy. Am J Psychiatry, 171 (10), 1056-1066. http://dx.doi.org/10.1176/appi.ajp.2014.14010121

Humphris, G. M., Longman, L. P. \& Field, E. A. (1996). Cognitive-behavioural therapy for idiopathic burning mouth syndrome: a report of two cases. Br Dent J, 181 (6), 204-208.

Ito, M., Kurita, K., Ito, T. \& Arao, M. (2002). Pain threshold and pain recovery after experimental stimulation in patients with burning mouth syndrome. Psychiatry Clin Neurosci, 56 (2), 161-168. http://dx.doi.org/950 [pii]10.1046/j.1440-1819.2002.00950.x

Jaaskelainen, S. K., Rinne, J. O., Forssell, H., Tenovuo, O., Kaasinen, V., Sonninen, P. \& Bergman, J. (2001). Role 
Giulio Fortuna / American Journal of Oral Medicine

(2016) Vol. 2 No. 1 pp. 11-20

of the dopaminergic system in chronic pain -- a fluorodopa-PET study. Pain, 90 (3), 257-260. http://dx.doi.org/S0304395900004097 [pii]

Jurisic Kvesic, A., Zavoreo, I., Basic Kes, V., Vucicevic Boras, V., Ciliga, D., Gabric, D. \& Vrdoljak, D. V. (2015). The effectiveness of acupuncture versus clonazepam in patients with burning mouth syndrome. Acupunct Med, 33 (4), 289-292. http://dx.doi.org/10.1136/acupmed-2015-010759 acupmed-2015-010759 [pii]

Just, T., Steiner, S. \& Pau, H. W. (2010). Oral pain perception and taste in burning mouth syndrome. J Oral Pathol Med, 39 (1), 22-27. http://dx.doi.org/10.1111/j.1600-0714.2009.00824.x JOP824 [pii]

Klasser, G. D., Epstein, J. B. \& Villines, D. (2011a). Management of burning mouth syndrome. J Can Dent Assoc, $77 \mathrm{~b} 151$.

Klasser, G. D., Epstein, J. B., Villines, D. \& Utsman, R. (2011b). Burning mouth syndrome: a challenge for dental practitioners and patients. Gen Dent, 59 (3), 210-220; quiz 221-212.

Klasser, G. D., Fischer, D. J. \& Epstein, J. B. (2008). Burning mouth syndrome: recognition, understanding, and management. Oral Maxillofac Surg Clin North Am, 20 (2), 255-271, vii. http://dx.doi.org/10.1016/i.coms.2007.12.012 S1042-3699(07)00138-0 [pii]

Ko, J. Y., Kim, M. J., Lee, S. G. \& Kho, H. S. (2012). Outcome predictors affecting the efficacy of clonazepam therapy for the management of burning mouth syndrome (BMS). Arch Gerontol Geriatr, 55 (3), 755761. http://dx.doi.org/10.1016/j.archger.2011.10.001 S0167-4943(11)00283-4 [pii]

Kuten-Shorrer, M., Kelley, J. M., Sonis, S. T. \& Treister, N. S. (2014). Placebo effect in burning mouth syndrome: a systematic review. Oral Dis, 20 (3), e1-6. http://dx.doi.org/10.1111/odi.12192

Lamey, P. J. \& Lewis, M. A. (1989). Oral medicine in practice: burning mouth syndrome. Br Dent J, 167 (6), 197-200.

Lauria, G., Majorana, A., Borgna, M., Lombardi, R., Penza, P., Padovani, A. \& Sapelli, P. (2005). Trigeminal small-fiber sensory neuropathy causes burning mouth syndrome. Pain, 115 (3), 332-337. http://dx.doi.org/S0304-3959(05)00131-4 [pii] 10.1016/j.pain.2005.03.028

Lin, H. P., Wang, Y. P., Chen, H. M., Kuo, Y. S., Lang, M. J. \& Sun, A. (2013). Significant association of hematinic deficiencies and high blood homocysteine levels with burning mouth syndrome. J Formos Med Assoc, $112(6), 319-325$. http://dx.doi.org/10.1016/j.jfma.2012.02.022 S0929-6646(12)00188-X [pii]

Lopez-Jornet, P., Camacho-Alonso, F. \& Andujar-Mateos, P. (2011a). A prospective, randomized study on the efficacy of tongue protector in patients with burning mouth syndrome. Oral Dis, 17 (3), 277-282. http://dx.doi.org/10.1111/i.1601-0825.2010.01737.x

Lopez-Jornet, P., Camacho-Alonso, F. \& De la Mano-Espinosa, T. (2011b). Complementary and alternative medical therapies in patients with burning mouth syndrome. J Altern Complement Med, 17 (4), 289290. http://dx.doi.org/10.1089/acm.2011.0026

Lopez-Jornet, P., Camacho-Alonso, F. \& Molino-Pagan, D. (2013). Prospective, randomized, double-blind, clinical evaluation of Aloe vera Barbadensis, applied in combination with a tongue protector to treat burning mouth syndrome. J Oral Pathol Med, 42 (4), 295-301. http://dx.doi.org/10.1111/jop.12002

Lopez-Jornet, P., Lucero-Berdugo, M., Castillo-Felipe, C., Zamora Lavella, C., Ferrandez-Pujante, A. \& PonsFuster, A. (2015). Assessment of self-reported sleep disturbance and psychological status in patients with burning mouth syndrome. J Eur Acad Dermatol Venereol, 29 (7), 1285-1290. http://dx.doi.org/10.1111/jdv.12795

Maina, G., Vitalucci, A., Gandolfo, S. \& Bogetto, F. (2002). Comparative efficacy of SSRIs and amisulpride in burning mouth syndrome: a single-blind study. J Clin Psychiatry, 63 (1), 38-43.

Malik, R., Goel, S., Misra, D., Panjwani, S. \& Misra, A. (2012). Assessment of anxiety and depression in patients with burning mouth syndrome: A clinical trial. J Midlife Health, 3 (1), 36-39. http://dx.doi.org/10.4103/0976-7800.98816 
Giulio Fortuna / American Journal of Oral Medicine

(2016) Vol. 2 No. 1 pp. 11-20

Marino, R., Torretta, S., Capaccio, P., Pignataro, L. \& Spadari, F. (2010). Different therapeutic strategies for burning mouth syndrome: preliminary data. J Oral Pathol Med, 39 (8), 611-616. http://dx.doi.org/10.1111/j.1600-0714.2010.00922.x JOP922 [pii]

Merksey, H., \& Bogduk, N. (1994). International Association for the Study of Pain. Descriptions of chronic pain syndromes and definitions of pain terms. In: Merskey H, Bugduk N, eds. Report by the IASP task force on taxonomy. Seattle, WA: IASP Press, pp. 74.

Mignogna, M. D., Pollio, A., Fortuna, G., Leuci, S., Ruoppo, E., Adamo, D. \& Zarrelli, C. (2011). Unexplained somatic comorbidities in patients with burning mouth syndrome: a controlled clinical study. J Orofac Pain, 25 (2), 131-140.

Muzyka, B. C. \& De Rossi, S. S. (1999). A review of burning mouth syndrome. Cutis, 64 (1), 29-35.

Palacios-Sanchez, B., Moreno-Lopez, L. A., Cerero-Lapiedra, R., Llamas-Martinez, S. \& Esparza-Gomez, G. (2015). Alpha lipoic acid efficacy in burning mouth syndrome. A controlled clinical trial. Med Oral Patol Oral Cir Bucal, 20 (4), e435-440. http://dx.doi.org/20410 [pii]

Pekiner, F. N., Demirel, G. Y., Gumru, B. \& Ozbayrak, S. (2008). Serum cytokine and T regulatory cell levels in patients with burning mouth syndrome. J Oral Pathol Med, 37 (9), 528-534. http://dx.doi.org/10.1111/j.1600-0714.2008.00668.x JOP668 [pii]

Pekiner, F. N., Gumru, B., Demirel, G. Y. \& Ozbayrak, S. (2009). Burning mouth syndrome and saliva: detection of salivary trace elements and cytokines. J Oral Pathol Med, 38 (3), 269-275. http://dx.doi.org/10.1111/j.1600-0714.2008.00734.x JOP734 [pii]

Petruzzi, M., Lauritano, D., De Benedittis, M., Baldoni, M. \& Serpico, R. (2004). Systemic capsaicin for burning mouth syndrome: short-term results of a pilot study. J Oral Pathol Med, 33 (2), 111-114. http://dx.doi.org/194n [pii]

Rodriguez-Cerdeira, C. \& Sanchez-Blanco, E. (2012). Treatment of burning mouth syndrome with amisulpride. J Clin Med Res, 4 (3), 167-171. http://dx.doi.org/10.4021/jocmr972w

Sardella, A., Lodi, G., Demarosi, F., Tarozzi, M., Canegallo, L. \& Carrassi, A. (2008). Hypericum perforatum extract in burning mouth syndrome: a randomized placebo-controlled study. J Oral Pathol Med, 37 (7), 395-401. http://dx.doi.org/10.1111/i.1600-0714.2008.00663.x JOP663 [pii]

Sardella, A., Lodi, G., Tarozzi, M., Varoni, E., Franchini, R. \& Carrassi, A. (2013). Acupuncture and burning mouth syndrome: a pilot study. Pain Pract, 13 (8), 627-632. http://dx.doi.org/10.1111/papr.12031

Sardella, A., Uglietti, D., Demarosi, F., Lodi, G., Bez, C. \& Carrassi, A. (1999). Benzydamine hydrochloride oral rinses in management of burning mouth syndrome. A clinical trial. Oral Surg Oral Med Oral Pathol Oral Radiol Endod, 88 (6), 683-686. http://dx.doi.org/S1079-2104(99)70010-7 [pii]

Scala, A., Checchi, L., Montevecchi, M., Marini, I. \& Giamberardino, M. A. (2003). Update on burning mouth syndrome: overview and patient management. Crit Rev Oral Biol Med, 14 (4), 275-291. http://dx.doi.org/14/4/275 [pii]

Schiavone, V., Adamo, D., Ventrella, G., Morlino, M., De Notaris, E. B., Ravel, M. G., . . Mignogna, M. D. (2012). Anxiety, depression, and pain in burning mouth syndrome: first chicken or egg? Headache, 52 (6), 1019-1025. http://dx.doi.org/10.1111/i.1526-4610.2012.02171.x

Silvestre, F. J., Silvestre-Rangil, J., Tamarit-Santafe, C. \& Bautista, D. (2012). Application of a capsaicin rinse in the treatment of burning mouth syndrome. Med Oral Patol Oral Cir Bucal, 17 (1), e1-4. http://dx.doi.org/17219 [pii]

Spanemberg, J. C., Cherubini, K., de Figueiredo, M. A., Gomes, A. P., Campos, M. M. \& Salum, F. G. (2012). Effect of an herbal compound for treatment of burning mouth syndrome: randomized, controlled, doubleblind clinical trial. Oral Surg Oral Med Oral Pathol Oral Radiol, 113 (3), 373-377. http://dx.doi.org/10.1016/j.0000.2011.09.005 S2212-4403(11)00683-3 [pii]

Sun, A., Lin, H. P., Wang, Y. P., Chen, H. M., Cheng, S. J. \& Chiang, C. P. (2013). Significant reduction of serum 
homocysteine level and oral symptoms after different vitamin-supplement treatments in patients with burning mouth syndrome. J Oral Pathol Med, 42 (6), 474-479.

http://dx.doi.org/10.1111/jop.12043

Valenzuela, S., Pons-Fuster, A. \& Lopez-Jornet, P. (2015). Effect of a 2\% topical chamomile application for treating burning mouth syndrome: a controlled clinical trial. J Oral Pathol Med, http://dx.doi.org/10.1111/jop.12412

Woda, A., Dao, T. \& Gremeau-Richard, C. (2009). Steroid dysregulation and stomatodynia (burning mouth syndrome). J Orofac Pain, 23 (3), 202-210.

Yamazaki, Y., Hata, H., Kitamori, S., Onodera, M. \& Kitagawa, Y. (2009). An open-label, noncomparative, dose escalation pilot study of the effect of paroxetine in treatment of burning mouth syndrome. Oral Surg Oral Med Oral Pathol Oral Radiol Endod, 107 (1), e6-11.

http://dx.doi.org/10.1016/j.tripleo.2008.08.024 S1079-2104(08)00625-2 [pii] 